Studia Anglica Posnaniensia 51/2, 2016

doi: 10.1515/stap-2016-0008

\title{
SOME PECULIAR FORMS OF OLD ENGLISH VERBS
}

\author{
MICHIKO OGURA*
}

Tokyo Woman's Christian University

\begin{abstract}
In late Old English it became common to find strange verb forms of which had less frequently appeared in earlier texts. It is clear that Old English paradigms started to modify their shapes, though their structure had never been completely established in the first place due to limited data. This article discusses some examples of Old English verbs which show a morphological merger in addition to phonetic, syntactic, or semantic resemblance, e.g., between wendan and gewendan, pyncan and pencan, leeran and leornian, (ge)witan and (ge)witan, blissian and bletsian, and biddan, (be)beodan, and forbeodan, so as to show the natural selection of Old English verbs in the process of lexical conflict.
\end{abstract}

Keywords: Old English, Middle English, verbs, morphology, synonyms

\section{Introduction ${ }^{1}$}

Old English is characterised by a significant number of synonyms. Nouns, adjectives, and adverbs which could occupy an alliterating position in poetry decreased in frequency as soon as alliterative poems were replaced by rhyming

* Corresponding author: Department of Literature and Culture in English, Tokyo Woman's Christian University, 2-6-1 Zempukuji, Suginami-ku, Tokyo 167-8585 Japan. E-mail: ogura.dainagon@jcom.home.ne.jp

1 This article is written under the strong inspiration of Stanley (2013), which points out some peculiar verb forms found in earlier editions of Old English texts. In the present-day situation web corpora are so prevalent and editions published in late 19th to early 20th century become so unavailable that such forms are often neglected to be examined. As I have studied semantic rivalry for years, I should like to focus on some unusual forms found in Old English texts and see if they are adequately explained in dictionaries and web corpora. 
poems, together with compounds, first elements of which were employed for alliteration. Verbs were not necessarily used for alliteration, except for infinitives and participles, but they also suffered conflict for survival. It is well attested by Gorrell (1895) that there was a rivalry between cweðan and secgan among the synonymous verbs of saying. The former took direct speech and the dative of person with the preposition to as the indirect object, while the latter governed indirect speech/questions and the dative of person without to; these syntactic features were gradually transferred from the former to the latter, and from the latter to tellan, around the time of transition from late Old to early Middle English, and eventually cweðan was fossilised and died out in Modern English. ${ }^{2}$ There is also an obvious confusion and merger between pyncan and pencan, an 'impersonal' verb and a personal one, especially between the preterite and the past participle forms buht(e) and poht(e), which is examined by van der Gaaf (1904). Thus the semantic rivalry may lead to syntactic changes, morphological mergers, and/or the replacement of one of the synonyms by a native or foreign synonym, and to the ultimate demise of the once flourishing word.

There must be cases of less obvious conflict caused by morphological resemblance, considering the fact that a number of Old English synonyms disappeared in the course of the language history. This cannot be explained away only by the prosodic change from alliterative to rhyming verse. There must be phonological and morphological as well as syntactic and semantic features that caused the conflict between synonyms or beyond groups of synonyms. In this paper I try to illustrate the process of morphological merger of several verbs through the extant texts of Old and Middle English periods in order to find the causes of their demise and survival.

\section{2. wendan and gewendan}

Wendan 'to turn' takes the accusative as a coreferential pronoun in the reflexive construction, while gewendan 'to turn' takes the dative, as in

(1) pa gebealh hine se cynincg and to his bedde eode.

wende hine to wage woodlice gebolgen.

'Then the king became angry and went to his bed, and turned himself to the wall, madly enraged.' (ÆLS (Book of Kings) 178-93)

(2) He forlet pa pat swurd stician on him 7 gewende him ut æt sumere opre duran, od pat he eft becom to his agenum geferon. 
'He then left the sword stuck on him and went himself out at another door, until he came again to his own comrades.' (Judges 3.24)

But in some instances the reverse is found, as in

(3) Nicanor ba sceawode salomones templ. and swor purh his godas poet he pæt godes hus wolde mid fyre forbærnan butan him man betæhte iudan gebundene to bismorlicum deaðe.

wende him swa awæg woodlice geyrsod.

'Nicanor then beheld Solomon's temple, and swore by his gods that he wished to burn up the house of God with fire, except Judas should be given up to him bound, (and) so turned himself away, madly enraged.' (ÆLS (Maccabees) 612-6)

(4) Đis wearð pa gekydd ðæm casere sona, \& he hine gewende to his gewunelicum gebedum \& pæt gewinn betæhte pam welwillendan Hælende.

'This was immediately made known to the emperor, and he went himself to his usual service, and entrusted the strife to the benevolent Saviour.' (ÆJudgEp 71)

From late Old English onwards the accusative-dative syncretism proceeds, and the prefix ge-disappears, and consequently the two verbs merge into one.

\section{3. pyncan and pencan}

pencan 'to think', a verb in personal use, and pyncan 'to seem', a verb in 'impersonal' ${ }^{4}$ use, are said to be confused in the preterite and the past participle forms, poht(e) and puht(e), as in

(5) C: per ich lai a sweueter agan ich forto slepe.

me puhte pat in pere weolcne: com an wunderlic deor.

O: par ich lay a sweuete: and ich gan to sleape.

me pohte in pare wolcne: com an deor sellich.

'Where I lay in slumber, (and) I began to sleep, it seemed to me that in the clouds came a marvelous beast.' (La3 25581-4)

$4 \quad$ I use the term 'impersonal' (with single quotes) to denote a verb with a personal object in the genitive/dative/accusative and with or without hit/poet as the subject. See Ogura (1986). 
But preceding this morpho-phonetic merger, some examples, in which the stem vowel -e- appears in pyncan, are attested in Old and Middle English texts, including van der Gaaf's (1904) example from the Old Kentish Sermon of the late thirteenth century.

(6) Hie him ponne eft swipe bitere pencap, æfter pon pe se deað him tocymep Godes dom to abeodenne.

'Then again they (the youthful lusts) will appear very bitter to him, after the death comes to him to announce the judgement of God.' (HomS 17 (BlHom 5) 76)

(7) po pe mest doð nu to gode. and pe lest to laðe. Eiðer to lutel and to muchel scal punchen [Dgb: penchen; $\operatorname{Eg}(2)$ : ðinche] eft hom bape.

'Those who do now the most as good and the least as evil. It must be thought both too little and too much.' (PMor (Lamb 487) 62)

(8) Inre fondunges beoð misliche unpeawes. oðer lust towart ham. oðer pohtes swikele pe pencheð [Nero: puncheð] ðah gode.

'Inner temptations are various vices, or the desire towards them, or thoughts which seem good but yet deceitful.' (Ancr (Corp-C 402) 94/17)

(9) bote yef ha luuie god almichti. and him serui:

al hit him may penche for-lore and idelnesse.

'unless they love God Almighty and serve him; all it may seem to them destruction and idleness' (Old Kentish Sermon 35.2 (Laud MS 471) (from van der Gaaf (1904: 78))

\section{4. lëran and leornian}

Leornian 'to learn' and lēran 'to teach' were strong candidates for morphological confusion, both starting with $l$ - and having front vowels which could be smoothed into -e-. In Ormulum the two verbs should in principle be differentiated by the length of the stem vowel through the spelling system peculiar to this text. But in examples (10) and (11), lerrnenn 'to learn'and lernenn 'to teach' appear, both of which go back to leornian. This means that OE leornian developed into ler(r)nenn with meanings both 'to learn' and 'to teach'.5

In White's glossary, the headword is written as "Leornenn, lernenn, to learn, to teach", which goes back to OE leornian. There is another headword, "Lærenn, to teach, instruct", which goes back to OE lēran. See Holt $(1878: 483,487)$. 
(10) Well mikell lerrnde Herode king

Off Crist, 7 off hiss come;

Forr bape he lerrnde well purrh hemm

Whatt da33, 7 whære o lande,

'King Herod learned very well of Christ and of his coming, for both he learned well through them, what day and where in the land...' (Orm 7248, 7250)

(11) Herr endep nu piss Goddspel puss,

$[\mathrm{T}$ u ] ss birpp itt purth sekenn,

To lokenn watt itt lernep uss

Off [ure] sawle nede.

'Here ends now this Gospel in this way and it is necessary for us to seek through, to observe what it teaches us of the need of our soul.' (Orm 19613)

In South-West Midland Lambeth Homilies the reflex of OE lexran appears as learnen, while the versions of Cursor Mundi with Northern traits have lern (Cotton) and larn (Göttingen) (the later Fairfax MS. shows lern). In the Wycliffite Bible, we find lernen in the Earlier Version corresponding to techen in the Later Version.

(12) 3if pe halia gast ne learð pes monnes heorte and his mod wið-innan: on idel beoð pes budeles word wið-utan icleopde.

'If the Holy Ghost does not teach man's heart and his mind inside, in vain are these words of preachers spoken from outside.' (Lamb Hom 95)

(13) C: In crist lai pat folk to lern;

G: In cristes lai pat folk to larn;

F: In goddes name that folk to lern (Cursor 19028)

(14) [qui erudite derisorem ipse sibi facit iniuriam]

Who lerneth [LV: techith] a scornere, doth wrong he to himself. (Wyc(EV) Prov. ix.7)

5. (ge)witan, (ge)wìtan and (be)witan

Witan 'to know' rarely occurs with the prefix ge-, while gewitan 'to go' scarcely appears without ge-. Examples (15) and (16) are such rare instances. 
(15) [unde mox egressi dinoscere quid esset]

Ond heo sona arison \& ut eodon; woldon gewitan hwæt pæt wære.

'And they arose at once and went out, desiring to know what that was.' (Bede 3 6.174.17)

(16) Nylle ic æfre hionan ut witan,

ac ic symle her softe wille

mid fæder willan fæste stondan.

'I will never go out from here, but I ever wish to stand here gently and firmly with father's will.' (Met 24 52b)

In Lazamon we find witen 'to know' and wìten 'to guard', which go back to witan and wìtan respectively. Moreover, biwiten, from OE bewitan 'to guard', appears in the Caligula MS. and the prefix $b i$ - often disappears in the Otho MS. In Cursor Mundi, wite 'to blame', from OE witan, is found in the same form in four manuscripts.

(17) C: pe ær weoren on pan londe: \& pa lawen wustē.

$\mathrm{O}$ : pe er weren in pat lond: and pe lawes wiste.

'who were before in the land, and knew the laws' (La3 1167)

(18) C: mid Humbres monnen. pe wuste Humberes fæi:

O: mid Humbert his mē. pat wiste Humbert his feo:

'with Humbert's men who took charge of Humbert's treasure' (La3 2221)

(19) C: pa weoren heo to priste: and to ufele heom biwustē.

... pat heo ne cuðen bi-witen heom:

O: $\quad$ o weren hii to priste: and to vuele zam wuste.

... pat hii ne coupe bi-wittie heom:

'Then they were too daring, and ruled them too evilly; (alas ...) that they could not guard themselves against their enemies.' (La3 27531-4)

(20) C: For-pi pat pou has don pe mis, piself pou wite pi wa, i-wis.

G: For-pi pat pu has don pe miss, pi seluen es pe wite pi wa, i wiss.

F: for-pi pat pou has done amys. pi-self may wite pi wa I. wys.

$\mathrm{T}$ : $\quad$ And pat pou hast pus don pis mis pi seluen is to wite I wis

'Because you have done amiss, you yourself are to blame (your woe), indeed.' (Cursor 876) 
These examples show multiple meanings or semantic ambiguity, the interchangeability of prefixes, and the orthographic deficiency of telling long vowels from short vowels in the reflexes of $\mathrm{OE}$ witan and witan. What we have today are the phrase to wit (cf. MS. T in (20)) and a Scottish or northern dialect form wite 'to blame'. 6

\section{6. blissian/blïpsian and bletsian}

The Dictionary of Old English (hereafter DOE) has headwords blissian/blippian and bletsian; both verbs had been rather distinct in meaning but phonetically similar except the stem vowel. According to the explanation in the Oxford English Dictionary (hereafter OED3), semantic confusion started from the construction in which God is the subject and the verb means 'to make happy'. Examples (21-23) are quoted from Genesis, in poetry and in the Hexateuch. As seen from (22) and (23), OE (ge)bletsian is used as a rendering of benedicere, but in the Wycliffite Bible, blisse is chosen in the Earlier version in contrast with blesse in the Later Version.

(21) Ic Ismael estum wille

bletsian nu, swa pu bena eart

pinum frumbearne,

'I wish to bless Ismael now willingly, as you are a petitioner to your firstborn son,' (GenA 2359a)

(22) [Et benedicam ei, et ex illa dabo tibi filium cui benedicturus sum,] Ic hi gebletsige, \& of hyre ic ðe forgyfe sunu, ðone ic wylle bletsian;

EV: and I shal blis to hir, and of hir I shal zyue to thee a sone, to whom I am to blis,

LV: and Y schal blesse hir, and of hir I schal 3yue to thee a sone, whom I schal blesse,

'and I shall bless her, and from her I shall give you a son, whom I shall bless' (Gen 17.16)

(23) [benedixique ei et erit benedictus]

$\&$ ic hyne bletsode, \& he byð gebletsod.

EV: and Y blisside hym? And he shal be blissid.

$6 \quad O E D 3$ has the following headwords: wit, $\mathrm{v}^{1}$ (f. OE witan 'to know'), wite/wyte, $\mathrm{v}^{1}$ (f. OE wìtan 'to blame'), †wite, $\mathrm{v}^{2}$ (f. OE witan, bewitan 'to keep, guard'), †wite, $\mathrm{v}^{3}$ (f. OE wìtan (rare), usually gewitan 'to go, depart'), †i-wite/ywite, $\mathrm{v}^{1}$ (f. OE gewitan 'to know; to watch, guard'), †i-wite, $v^{2}$ (f. OE gewitan 'to go, depart')

7 OED 3 , bless, $v^{1}$. III. 7. a. 
LV: and Y blesside him? And he schal be blessed.

'and I blessed him, and he shall be blessed' (Gen 27.33)

The confusion continues throughout the medieval period and beyond. Two examples are given in addition. ${ }^{8}$

(24) Wel may pe barne blisse [C. text blesse] pat hym to boke sette. (1377 Langland Piers Plowman B. xii. 187)

(25) Withe suche I loue not to meddle. God blysse me from them. (1543 T. BECON New Yeares Gyfte sig. C. iv $(O E D)$ )

\section{7. biddan, bēodan, for(e)bēodan, and bebēodan}

It is stated under the headword bid $\mathrm{v}^{1}$ in $O E D 3$ that OE biddan 'to ask' and be odan 'to command' merged completely in the course of the fourteenth to the fifteenth century. ${ }^{9}$ Forbid, which is the proof of the morphological merger between biddan and forbēodan, first appeared in 1573 in the infinitive form to forbidde ${ }^{10}$ Ahead of this merger, however, we find a possible interchangeability of bebēodan and forbēodan in manuscripts Cotton Claudius B. iv and CUL Ii. 1. 33. It is caused by a syntactic feature of forbēodan that a negative particle ne tends to appear pleonastically in a pat-clause governed by a verb of negative import.

(26) [Cur præcepit uobis Deut, ut non comederetis de omni ligno Paradisi?] Hwi forbead [C: bebead] God eow ðæt ge ne æton of ælcon treowe binnan Paradisum?

'Why did God forbid you that you should (not) eat of each tree inside the Paradise?' (Gen(B) 3.1)

(27) [Quis enim indicauit tibi quod nudus esses, nisi quod ex ligno de quo præceperam tibi ne comederes, comedisti?]

Hwa sæde ðe ðæt ðu nacod wære, gyf ðu ne æte of ðam treowe ðe ic ðe bebead [C: forbead] ðæt ðu ne æte.

Example (25) is quoted from $O E D 3$, bless, $\mathrm{v}^{1}, \mathrm{I}, \dagger 3$. a

As explained in Sweet (1882, rev. 1953: 28 and 30), bēodan and biddan conjugate as follows: bēodan (biett), bēad, budon, boden, and biddan (bitt), baed, bēedon, beden. A possible morphological confusion could have occurred in the third person present singular forms, biett and bitt.

10 See $O E D 3$, forbid, v., f. 2. a. Campbell states that unrounding of the second element of diphthongs is seen as a Kentish feature and gives the form forbiet 'he forbids' among examples (1959: 119); the form is cited in $D O E$ from $C P$ 48.369.1 (s.v. for-bēodan, forebeodan, Vb. st. 2, 1. d. ii.). See $D O E, A$ to $G$ on $C D-R O M$. 
'Who told you that you were naked, if you did not eat of the tree which I forbade you that you should (not) eat?' (Gen(B) 3.11)

Thus there is also an example in Mark, where a negative construction in a paetclause causes the West Saxon version to choose forbēodan in contrast with bebeodan in Lindisfarne and Rushworth 1 versions. ${ }^{11}$

(28) [et uehementer cominabatur eis né manifestarent illum]

Li: $\quad T$ swiðe bebead him tote hia ne æwades 1 mersades hine

Rul: $\quad \quad \quad$ swiðe bibead him $\$$ hiæ ne eowde him

WSCp: $\quad T$ he him swyðe forbead. $\$$ hi hine ne ge-swutelodon.

WycEV And gretely he manasside hem, that thei shulden nat make hym opyn $[L V$ : knowun]

Tyn: And he streyghtly charged them, that they shulde not vtter him.

AV: $\quad$ And he straitly charged them, that they should not make him knowen. (Mk 3.12)

As a rendering of prohibere, the form forbidde occurs in an interlinear gloss (MS Cotton Tiberius A. iii). DOE has this in attested spellings. ${ }^{12}$ This may suggest an embryonic form of the morphological ambiguity in the middle of the eleventh century.

(29) [si linguam ad loquendum prohibeat monachus] gif tungan to sprecanne gif forbidde se munuc 'if the monk would forbid to speak the language' (BenRG1 7.35.1)

Concerning the merger of non-prefixed biddan and bēodan, DOE discusses the wide semantic range of biddan, i.e. 'to ask, pray, exhort, urge, direct, enjoin, command', and suggest that the possible confusion with bèodan could have occurred in the sense 'to command' ${ }^{13}$ Example (30) with explanation is quoted from $D O E$.

(30) eall hit bið swa ðu bidest (from bidest perh. shows confusion with pres. ind. 2nd sg. of beedan). (LS 5 (InventCrossNap) 446 (DOE; = HRood 28.19))

11 Forbead in $R u 2(M k 7.36)$ is a form of forebēodan (=forbēodan). See DOE, the reference in the previous footnote.

12 See $D O E$, for-bēodan, fore-bēodan.

13 DOE, biddan, Vb., st. 5. 
Similar constructions appear in late OE Martyrology (Cotton Junius A. x): Mart 5 (Kotzor) Jn2, A. 31 Eall hit bið swa pu bidest, Ap28, B.33 Swa hit bið swa swa pu bidest (DOE). Among the attested spellings of biddan and beodan, three forms are found in common: bit, bed, and bede. Bit in example (31) may be a form of biddan,,$^{14}$ and so could be the case of bit in (32). ${ }^{15}$ Bit in (33) appears as a variant of bebyt (f. bebēodan).

(31) swa man us bit and lærð, 'as we are commanded and taught' (HomU26 (Nap 29) 73)

(32) La Israhel, ne bit God ðe nanes ðinges, buton ðæt ðu ondræde Drihten ðinne Godd \& lufie hine

'Ah Israel, God does not command you anything, except that you should fear Lord your God and love him’ (Deut 10.12)

(33) swa hwæt swa he eow bebyt [B. bit]. doð pæt 'whatever he commands you, do that' (ÆCHom II, 4 29.10)

Biddan takes the accusative and the genitive, and beodan the dative. In (34) and (35) from the Peterborough Chronicle the dative occurs with bed, while in (36) from Charter 1428 we find the unambiguous accusative.

(34) \& bed him pet he scolde pet geten mid his writ \& mid his bletsunge. 'and asked him that he should say yes to it with his writing and with his blessing' (ChronE (Irvine) 675.3)

(35) Đa hi wæron pær gegaderod, pa bed se kyng heom pæt hi scoldon cesen hem ærcebiscop to Cantwarabyrig swa hwam swa swa hi woldon, \& he hem hit wolde typian.

'When they were all assembled there, then the king asked them that they should choose for themselves an archbishop of Canterbury, whomsoever they wished, and he wished to grant it to them.' (ChronE (Irvine) 1123.17)

14 Cf. LawICn 7 (DOE biddan, 5.a.iii.) And we laerad \& biddad \& on Godes naman beodad, paet cenig Cristen mann binnan VI manna sibfcece on his agenum cynne afre ne gewifie, (cf. Quadr.: commonemus, petimus et in nomine Dei precipimus) 'And we teach and command and bid in the name of God that any Christian man should never take a wife within the sixth degree of affinity in his own race'

15 Latin is petit. See Crawford (1922). 
(36) Ic eode to minan abode Ælfwine \& bed hinæ pæt ic moste norb faran to pan halgan \& hine gesecan. (Ch 1428 (Harm 113) 4)

$\&$ bed hine pæt he scolde settan gode lagan... (Ch 1428 (Harm 113) 28)

Bede in (37) is a form of biddan, while (38) it apears in the attested spelling of the twelfth century. ${ }^{16}$

(37) [serue nequam omne debitum dimisi tibi quoniam rogasti me]

Li: $\quad$ degn 1 esne wohfull eghuelc scyld forgeaf ic ðe forðon ðu bede mec

Ru1: $\quad$ esne nawiht ealle pa scylde ic forlet pe forpon ðe pu bede me

WSCp: Eala pu lypra peowa eallne pinne gylt ic ðe forgeaf. for-pam pe ðu me bæde.

WycEV: Weyward seruaunt, I forzaf to thee al the dette, for thou preidist me.

AV: $\quad$ O thou wicked seruant, I forgaue thee all that debt because thou desiredst me: (Mt 18.32)

(38) \& ic nille pafien pat men hem ani unriht bede.

'and I do not want to allow them to be commanded any wrong' (Ch 1072 (Harm 12) 5)

\section{Summary}

A morphological merger has accelerated the conflict among synonyms and lessened the number of synonyms. The causes of the choice were phonological, ${ }^{17}$ morphological, syntactic, and semantic similarities. Two (or more) verbs merged into one, as in pyncan and pencan, wendan and gewendan, blissian and bletsian, became fossilised or dialectal like (ge)witan and (ge)wittan, or merged and gave birth to another prefixed verb like biddan, bèodan, and forbèodan. These points of conflict can be summarised as follows:

DOE, bēodan, Vb., st. 2.

17 An example can be added. Wergan 'to curse' develops into wary, and wregan 'to accuse', wray, after having produced numbers of different forms; both are now obsolete as shown with daggers by $O E D 3$. The two verbs did not show obvious traces of confusion until the end of the fourteenth century. In the following example from $M E D$ the metathesis occurs, even though wreyen takes reflexive constructions in Old and Middle English while wereyen does not: c1400 Wrey py self (Cmb Ii.3.8) p. 80 Werey [alt. to: Wrey] pyself als a pef doz; say pou sotz and nozynge ozer. (Verbs in question are highlighted.) 
Table 1. Possible pathways of development of verbal pairs

\begin{tabular}{|c|c|c|c|c|}
\hline $\begin{array}{l}\text { points } \\
\text { of conflict }\end{array}$ & phonological & morphological & syntactic & semantic \\
\hline $\begin{array}{l}\text { wendan \& } \\
\text { gewendan }\end{array}$ & & ge- or $\varnothing$ & $\begin{array}{l}+ \text { accusative or } \\
+ \text { dative }\end{array}$ & 'to turn' \\
\hline $\begin{array}{l}\text { pyncan \& } \\
\text { pencan }\end{array}$ & [i], [e], [y] & $\begin{array}{l}\text { pinche/penche; } \\
\text { puht(e)/poht(e) }\end{array}$ & $\begin{array}{l}\text { 'impersonal' or } \\
\text { personal }\end{array}$ & $\begin{array}{l}\text { 'to think', } \\
\text { 'to seem' }\end{array}$ \\
\hline $\begin{array}{ll}\text { læran } & \& \\
\text { leornian } & \\
\end{array}$ & {$[\mathfrak{e}],[\mathrm{e}],[\mathrm{a}]$} & $\begin{array}{l}\text { leorne/lerne/ } \\
\text { larne }\end{array}$ & & $\begin{array}{l}\text { 'to teach', } \\
\text { 'to learn' }\end{array}$ \\
\hline $\begin{array}{l}\text { (ge)witan \& } \\
\text { (ge)wìtan }\end{array}$ & [i], [i:] & ge- or $\varnothing$ & & 'to guard' \\
\hline $\begin{array}{l}\text { blissian \& } \\
\text { bletsian }\end{array}$ & [i], [e] & blisse/blesse & & $\begin{array}{l}\text { 'to make } \\
\text { happy' }\end{array}$ \\
\hline $\begin{array}{l}\text { (for)bēodan \& } \\
\text { biddan }\end{array}$ & {$[-\mathrm{e}-],[-\mathrm{i}-]$} & $\begin{array}{l}\text { for- or Ø } \\
\text { forbidde }\end{array}$ & $\begin{array}{l}\text { (be)bēodan/ } \\
\text { forbēodan + } \\
\text { pæt ... ne }\end{array}$ & $\begin{array}{l}\text { 'to command } \\
\text { not to', } \\
\text { 'to forbid' }\end{array}$ \\
\hline
\end{tabular}

Which verb is to be preferred and survive depends on chance. Verbs with less ambiguous forms or newcomers from foreign languages may be given a chance to replace the synonyms with more confusing forms and survive into Modern English. Major syntactic and semantic features of each verb are rather easily attested, but the possible examples of morphological merger are rarely identified. Only manuscript variants and different lexical choices in similar contexts can be the proof of the process of the merger.

\section{REFERENCES}

\section{PRIMARY SOURCES}

Bosworth, Joseph \& George Waring (eds.). 1888. The Gothic and Anglo-Saxon Gospels in parallel columns with the versions of Wycliffe and Tyndale. London: Reeves \& Turner.

Crawford, S. J. (ed.). 1922. The Old English version of the Heptateuch, Aelfric's treatise on the Old and New Testament and his Preface to Genesis. (EETS, o.s. 160.) London: Oxford University Press.

DOE $=$ Dictionary of Old English A - G on CD-ROM. Fascicle $G$ and Fascicles $A$ to $F$ (with revisions).

Dictionary of Old English web corpus. http://www.doe.utoronto.ca/doecorpus/.

Holt, Robert (ed.), 1878. The Ormulum with the notes and glossary of Dr. R. M. White. Oxford: Clarendon Press.

Madden, Frederic (ed.). 1847. Lazamon's Brut, or Chronicle of Britain; a poetical semi-Saxon paraphrase of the Brut of Wace. London: Society of Antiquaries of London.

$\mathrm{MED}=$ Middle English dictionary, http://quod.lib.umich.edu $/ \mathrm{m} / \mathrm{med} /$. 
Napier, Arthur S. (ed.). 1894. History of the holy rood-tree, a twelfth century version of the cross legend. (EETS, o.s. 103.) London: Paul, Trench, Trübner \& Co., Limited.

OED = Oxford English dictionary (3rd edn.), http://www.oed.com/.

Skeat, Walter. W. (ed.). 1871-1887. The Gospel according to Saint Matthew and according to Saint Mark; The Gospel according to Saint Luke and according to Saint John. Cambridge: Cambridge University Press.

\section{SECONDARY SOURCES}

Campbell, Alistair. 1959. Old English grammar. Oxford: Clarendon Press.

Gaaf, Willem van der, 1904. The transition from the impersonal to the personal construction in Middle English. (Anglistische Forschungen 14.) Heidelberg: Carl Winter.

Gorrell, Joseph H. 1895. Indirect discourse in Anglo-Saxon. PMLA 10.3. 342-485.

Ker, Neil R. 1957. Catalogue of manuscripts containing Anglo-Saxon. Oxford: Clarendon Press.

Laing, Margaret. 1993. Catalogue of sources for a linguistic atlas of early medieval English. Cambridge: D. S. Brewer.

Mitchell, Bruce. 1985. Old English syntax. Oxford: Clarendon Press.

Mustanoja, Tauno F. 1960. A Middle English syntax. Helsinki: Société Néophilologique.

Ogura, Michiko. 1981. The syntactic and semantic rivalry of QUOTH, SAY and TELL in Medieval English. (Intercultural Institute Research Monograph No. 12.) Osaka: Kansai University of Foreign Studies.

Ogura, Michiko. 1986. Old English 'impersonal' verbs and expressions. (Anglistica 24.) Copenhagen: Rosenkilde and Bagger.

Stanley, Eric G., 2013. Unlikely-looking Old English verb forms. In Andreas H. Jucker, Daniela Landert, Annina Seiler \& Nicole Studer-Joho (eds.), Meaning in the history of English: Words and texts in context, 39-60. (Studies in Language Companion Series 148.) Amsterdam/Philadelphia: John Benjamins.

Sweet, Henry. 1982. Sweet's Anglo-Saxon primer. Revised throughout by Norman Davis. (9th edn.) Oxford: Clarendon Press.

Visser, Fredericus Th. 1963-1973. An historical syntax of the English language. Leiden: Brill. 